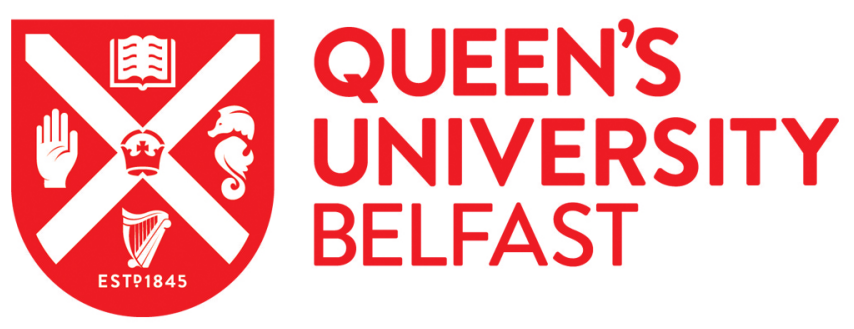

\title{
Ambient Temperature Hydrocarbon Selective Catalytic Reduction of NOx Using Atmospheric Pressure Nonthermal Plasma Activation of a Ag/Al2O3 Catalyst
}

Stere, C. E., Adress, W., Burch, R., Chansai, S., Goguet, A., Graham, W. G., De Rosa, F., Palma, V., \& Hardacre, C. (2014). Ambient Temperature Hydrocarbon Selective Catalytic Reduction of NOx Using Atmospheric Pressure Nonthermal Plasma Activation of a Ag/Al2O3 Catalyst. ACS Catalysis, 4(2), 666-673. https://doi.org/10.1021/cs4009286

\section{Published in:}

ACS Catalysis

\section{Document Version:}

Peer reviewed version

Queen's University Belfast - Research Portal:

Link to publication record in Queen's University Belfast Research Portal

\author{
Publisher rights \\ (c) 2014 American Chemical Society
}

This document is the Accepted Manuscript version of a Published Work that appeared in final form in ACS Catalysis, copyright $\odot$ American Chemical Society after peer review and technical editing by the publisher.

To access the final edited and published work see http://pubs.acs.org/doi/abs/10.1021/cs4009286 and see http://pubs.acs.org/page/policy/articlesonrequest/index.html for more information.

\section{General rights}

Copyright for the publications made accessible via the Queen's University Belfast Research Portal is retained by the author(s) and / or other copyright owners and it is a condition of accessing these publications that users recognise and abide by the legal requirements associated with these rights.

\section{Take down policy}

The Research Portal is Queen's institutional repository that provides access to Queen's research output. Every effort has been made to ensure that content in the Research Portal does not infringe any person's rights, or applicable UK laws. If you discover content in the Research Portal that you believe breaches copyright or violates any law, please contact openaccess@qub.ac.uk. 


\title{
Ambient temperature hydrocarbon selective catalytic reduction of $\mathrm{NO}_{\mathrm{x}}$ using atmospheric pressure non-thermal plasma activation of a $\mathrm{Ag} / \mathrm{Al}_{2} \mathrm{O}_{3}$ catalyst
}

Cristina E. Stere ${ }^{1}$, Wameedh Adress ${ }^{2}$, Robbie Burch ${ }^{1}$, Sarayute Chansai ${ }^{1}$, Alexandre Goguet, William G. Graham*2, Fabio De Rosa ${ }^{1,3}$, Vincenzo Palma ${ }^{3}$ and Christopher Hardacre ${ }^{*}, 1$

${ }^{1}$ Centre for the Theory and Application of Catalysis, CenTACat, School of Chemistry and Chemical Engineering, Queen's University Belfast, Belfast, N. Ireland, U.K.

${ }^{2}$ Centre for Plasma Physics, School of Mathematics and Physics, Queen's University Belfast, N. Ireland, U.K

${ }^{3}$ Dipartimento di Ingegneria Industriale, Università di Salerno, Via Ponte Don Melillo 84084 Fisciano (SA), Italy

Corresponding author: $\left({ }^{*}\right)$ c.hardacre@qub.ac.uk,b.graham@qub.ac.uk

\begin{abstract}
Atmospheric pressure non-thermal plasma activated catalysis for the removal of $\mathrm{NO}_{\mathrm{x}}$ using hydrocarbon selective catalytic reduction has been studied utilising toluene and $n$-octane as the hydrocarbon reductant. When the plasma was combined with an $\mathrm{Ag} / \mathrm{Al}_{2} \mathrm{O}_{3}$ catalyst a strong enhancement in activity was observed when compared with conventional thermal activation with high conversions of both $\mathrm{NO}_{\mathrm{x}}$ and hydrocarbons obtained at temperature $\leq 250{ }^{\circ} \mathrm{C}$, where the silver catalyst is normally inactive. Importantly, in the absence of an external heat source, significant activity was obtained at $25^{\circ} \mathrm{C}$. This low temperature activity provides the basis for applying non thermal plasmas to activate emission control catalysts during cold start conditions which remains an important issue for mobile and stationary applications.
\end{abstract}

Keywords: $\mathrm{Ag} / \mathrm{Al}_{2} \mathrm{O}_{3}$, Non-thermal plasma jet, $\mathrm{NO}_{\mathrm{x}}$ reduction, low temperature hydrocarbon selective catalytic reduction, toluene, $n$-octane 


\section{Introduction}

Catalysis is an essential enabling technology which impacts on the quality and economics of our lives. It holds the key to solving many problems facing society, among which automotive emission control and clean energy production. Stringent emission regulations have led to innovative research and the development of efficient technologies for pollution control both for stationary and mobile applications. Among these, Selective Catalytic Reduction (SCR) by hydrocarbons (HC) has shown a high potential in the removal of $\mathrm{NO}_{\mathrm{x}}$ emissions from diesel and lean burn gasoline engines [1-13]. $\mathrm{Ag} / \mathrm{Al}_{2} \mathrm{O}_{3}$ catalysts have been widely studied for this reaction as they have been shown to be highly selective to $\mathrm{N}_{2}$ versus $\mathrm{N}_{2} \mathrm{O}$ and have moderate tolerance to water vapor and $\mathrm{SO}_{2}[5,8,9,12,13]$. However, a significant drawback of the Agbased systems is their lack of activity below $350^{\circ} \mathrm{C}$, therefore, control of the reaction conditions would be key for practical use. These systems have significant issues associated with cold start conditions where very poor $\mathrm{NO}_{\mathrm{x}}$ reduction activity is observed.

Recently, electrically produced plasma based processes have been reported as an attractive alternative to conventional thermally activated reactions. This interest stems from the fact that often times the highly reactive species in the plasma are not in thermodynamic equilibrium. Depending on the amount of energy and the details of how it is coupled into the plasma, the plasma can be classified as thermal or non-thermal. Non-thermal plasmas (NTPs) are in highly non-equilibrium state characterized by high temperatures electrons of several thousands of degrees while the background gas molecules/ions are close to ambient temperature. The main advantage of NTPs is that they can enable thermodynamically unfavourable reactions to occur at low temperatures; however, the selectivity towards the products of interest is not always optimal $[14,15]$. Therefore, the combination of heterogeneous catalysis with plasmas has attracted interest due to the combined possible advantages of having fast and low-temperature reaction from atmospheric non-thermal plasma and high product selectivity from heterogeneous catalysis. Hybrid plasma-catalyst systems have proven to be very efficient in promoting the activity in VOC oxidation, automotive catalysis, water purification, reforming and hydrogenation reactions [15-24].

In many cases, the NTP is placed upstream of the catalyst bed $[17,25,26]$ and activates the gas prior to contacting with the surface of the catalyst. For example, Rappé et al. [26] reported $\sim 80 \%$ reduction of $\mathrm{NO}_{\mathrm{x}}$ in a simulated lean exhaust over a $\mathrm{Ba} /$ zeolite $\mathrm{Y}$ and $\mathrm{Ag} / \gamma$-alumina catalytic system at $200{ }^{\circ} \mathrm{C}$ with the plasma upstream of the catalyst bed. Li et al. [9] also 
reported an increase in $\mathrm{NO}_{\mathrm{x}}$ conversion from $\sim 30 \%$ to $>85 \%$ at $340{ }^{\circ} \mathrm{C}$ over silver based catalysts when the reaction gas was activated by NTP. Cho and co-workers [27] studied the plasma-assisted hydrocarbon selective catalytic reduction (HC-SCR) system using oxygenated hydrocarbons produced by a diesel fuel reformer and reported on the beneficial effect of a plasma on both the $\mathrm{NO}_{\mathrm{x}}$ and $\mathrm{HC}$ conversion at $200^{\circ} \mathrm{C}$. Importantly, further enhancements were achieved by placing the catalyst in the discharge area [9, 18, 28]. Li et al. [9] studied the effect of plasma on the $\mathrm{NO}_{x}$ storage capacity (NSC) of a $\mathrm{Pt} / \mathrm{Ba} / \mathrm{Al}_{2} \mathrm{O}_{3}$ catalyst between $100-300{ }^{\circ} \mathrm{C}$. Compared with only thermally activating the catalyst, an increase of up to $50 \%$ of the NSC was reported in a two-stage system, with the catalyst downstream the plasma-system, whereas in a single-stage plasma-catalyst system, with the catalyst placed inside the discharge area, the NSC increased by up to $91 \%$ compared with the catalyst-only over the same temperature range. Than Quoc An et al. [18] and Harling et al. [28] emphasized the higher efficiency of a onestage-plasma-catalyst system compared with a two-stage configuration in the destruction of aromatics for environmental clean-up at room temperature. Harling et al. reported $65 \%$ destruction of toluene and $49 \%$ destruction of benzene using $\mathrm{Ag} / \mathrm{Al}_{2} \mathrm{O}_{3}$ as the catalyst in a onestage plasma-catalysis configuration compared with $28 \%$ and $39 \%$, respectively, for the twostage configuration. They attributed the enhancement in hydrocarbon destruction to the direct interaction of the radicals, electrons and photons created by the plasma with the catalyst and molecules adsorbed on its surface. A recent example of plasma-catalyst hybrid systems with potential applications for stationary sources [29] showed promising results for low-temperature deNO $\mathrm{N}_{\mathrm{x}}$ under simulated flue gas conditions. In a combined adsorption-discharge plasma process, the adsorbed $\mathrm{NO}_{\mathrm{x}}$ was efficiently decomposed over a H-ZSM-5 catalyst to $\mathrm{N}_{2}$ and $\mathrm{O}_{2}$ during the discharge stage, in oxygen-deficient air and with very low space velocities. However, the addition of $2 \%$ water in the simulated flue gas caused a significant reduction in conversion. The deNO $\mathrm{N}_{\mathrm{x}}$ efficiency of the zeolite was improved by injecting $2.5 \% \mathrm{NH}_{3}$ during the discharge stage. The properties observed for combined catalyst-plasma systems show some promise for the selective $\mathrm{NO}_{\mathrm{x}}$ reduction by hydrocarbons over $\mathrm{Ag} / \mathrm{Al}_{2} \mathrm{O}_{3}$ catalysts since the activation or partial oxidation of the hydrocarbons has been shown to be a controlling step in the formation of $\mathrm{N}_{2}$ as a product $[9,27,30]$. Furthermore, the increased performance at low temperature of plasma assisted process compared with thermally activated processes may hold the solution to cold start emission control. $\mathrm{NO}_{\mathrm{x}}$ reduction during cold start periods is still a key issue for meeting the future emission regulations since most of the noxious emissions are released during the period when the catalysts temperature is insufficiently high to be fully 
active. The use of NTP for low-temperature emission control may overcome such problems [31-33].

In the present paper, we report evidence of non-thermal plasma assisted hydrocarbon selective catalytic reduction $(\mathrm{HC}-\mathrm{SCR}) \mathrm{deNO}_{\mathrm{x}}$ reaction over a silver-based catalyst using $\mathrm{He}$ as the discharge medium. The latter was used to enable a study of whether low temperatures $\left(25-250{ }^{\circ} \mathrm{C}\right)$ could be employed for the removal of $\mathrm{NO}_{\mathrm{x}}$ using simulated diesel fuels (toluene or n-octane).

\section{Experimental}

\subsection{Catalyst preparation}

The Ag catalyst provided by Johnson Matthey was prepared byimpregnation of an $\gamma$ $\mathrm{Al}_{2} \mathrm{O}_{3}$ support (LaRoche Industries Inc.). The support material was ground and sieved to a particle size of 150-250 $\mu \mathrm{m}$ and mixed with a solution containing $0.022 \mathrm{M} \mathrm{AgNO}_{3}$. The catalyst was then filtered, dried at room temperature for $24 \mathrm{~h}$ and further dried at $100{ }^{\circ} \mathrm{C}$ for $3 \mathrm{~h}$, after

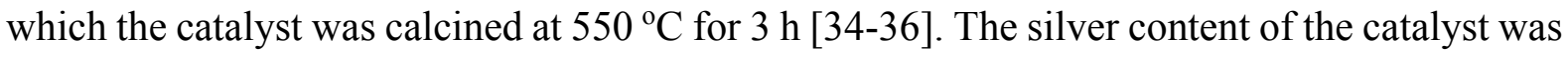
determined, using Inductively Coupled Plasma-Optical Emission Spectroscopy (ICP-OES), to be $2 \mathrm{wt} \% \mathrm{Ag}$ [34-36] and the BET specific surface area was $170 \mathrm{~m}^{2} \mathrm{~g}^{-1}$.

\subsection{Activity tests}

The experiments were designed to obtain information on the activity of the SCR catalyst when atmospheric pressure helium was used and the non-thermal plasma jet was in direct contact with the catalyst bed. The $2.0 \% \mathrm{Ag} / \mathrm{Al}_{2} \mathrm{O}_{3}$ catalyst sample (100 mg) was placed in the centre of a fixed-bed flow reactor system, consisting of a $4 \mathrm{~mm}$ I.D. T-shape quartz reactor tube (Figure 1a). Typically, the catalyst was held in place between plugs of quartz wool and a K-type grounded thermocouple was placed in the centre of the catalyst bed for temperature measurements in the absence of plasma. In the presence of NTP, the gas temperature was determined by analyzing the rotational $\mathrm{N}_{2}$ plasma spectrum structure [37-39]. An Ocean Optics imaging spectrometer was used to record the spectra, which were then compared with simulated spectra of the $0-0$ band of the second positive system of nitrogen at different temperatures. A least square procedure using Newton-Gauss algorithm was used to get the best fit between the experimental and theoretical spectral bands [37].

The SCR gas feed stream was flowed through the horizontal tube from one side of the reactor and through the catalystwhile the atmospheric pressure helium for the non-thermal 
plasma jet was flowed through the vertical arm onto the catalyst, as shown in Figure 1. Helium was fed into the reactor with a flow rate of $100 \mathrm{~cm}^{3} \mathrm{~min}^{-1}$.

The total flow rate and space velocity of the SCR mixture were $276 \mathrm{~cm}^{3} \mathrm{~min}^{-1}$ and 165,600

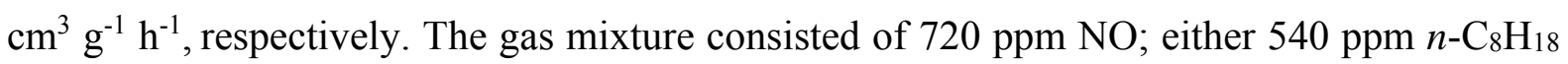
or $620 \mathrm{ppm}$ toluene (corresponding to $4340 \mathrm{ppm}$ as $\mathrm{C} 1$ ); $4.3 \% \mathrm{O}_{2}, 7.2 \% \mathrm{H}_{2} \mathrm{O} ; 7.2 \% \mathrm{CO}_{2}$ and He as the carrier gas. All the gases were supplied by BOC and each was individually controlled by an Aera ${ }^{\mathrm{TM}} \mathrm{FC}-7700 \mathrm{C}$ mass flow controller. The $n$-octane, toluene and water vapour were introduced by passing $\mathrm{He}$ as a carrier gas through separate custom-made saturators. The hydrocarbon saturator was placed in an ice/water bath and the $\mathrm{H}_{2} \mathrm{O}$ saturator temperature was controlled using a Grant ${ }^{\mathrm{TM}}$ GD120 thermostatic bath. All the pipework following the water saturator was heat tracedto prevent condensation.

The exit of the reactor was connected in series to a Signal 4000VM series chemiluminescence detector, used to analyze the inlet and outlet $\mathrm{NO}_{\mathrm{x}}$ concentrations and a Bruker Tensor 27 Fourier Transform Infra-Red spectrometer (FTIR), fitted with a gas cell of volume $190 \mathrm{~cm}^{3}$ or a Hiden Analytical HPR20 mass spectrometer (MS). The hydrocarbon conversion, gas phase $\mathrm{CO}$ and $\mathrm{N}_{2} \mathrm{O}$ were monitored by FTIR and the MS was used to monitor the formation of $\mathrm{N}_{2}$. To quantify the dinitrogen formed, isotopically labelled ${ }^{15} \mathrm{NO}(\mathrm{m} / \mathrm{z}=31)$ was used as a reactant and the production of ${ }^{15} \mathrm{~N}_{2}(\mathrm{~m} / \mathrm{z}=30)$ was monitored in order to avoid any interference from the fragmentation derived from the $7.2 \% \mathrm{CO}_{2}(\mathrm{~m} / \mathrm{z}=28)$ or any $\mathrm{CO} / \mathrm{CO}_{2}$ formed during the reaction. Argon was used as a tracer and internal standard. The temperature of the reaction was controlled with a calibrated hot air blower. The following equations were used to calculate the conversion of $\mathrm{NO}_{\mathrm{x}}$ and hydrocarbon as well as the $\mathrm{N}_{2}, \mathrm{~N}_{2} \mathrm{O}, \mathrm{CO}_{2}$ and $\mathrm{CO}$ selectivities:

$$
\begin{aligned}
& N O_{x} \text { conversion }(\%)=\frac{\left[N O_{x}\right]_{\text {in }}-\left[N O_{x}\right]_{\text {out }}}{\left[N O_{x}\right]_{\text {in }}} \times 100 \\
& \text { Hydrocarbon conversion }(\%)=\frac{[H C]_{\text {in }}-[H C]_{\text {out }}}{[H C]_{\text {in }}} \times 100 \\
& N_{2} \text { selectivity }(\%)=\frac{2\left[N_{2}\right]}{\left[N O_{x}\right]_{\text {in }}-\left[N O_{x}\right]_{\text {out }}} \times 100 \\
& \mathrm{~N}_{2} \mathrm{O} \text { selectivity }(\%)=\frac{2\left[\mathrm{~N}_{2} \mathrm{O}\right]}{\left[\mathrm{NO}_{x}\right]_{\text {in }}-\left[\mathrm{NO}_{x}\right]_{\text {out }}} \times 100 \\
& \mathrm{CO}_{2} \text { selectivity }(\%)=\frac{\left[\mathrm{CO}_{2}\right]}{x \times\left\{\left[\mathrm{C}_{x} \mathrm{H}_{y}\right]_{\text {in }}-\left[\mathrm{C}_{x} \mathrm{H}_{y}\right]_{\text {out }}\right\}} \times 100 \\
& \text { CO selectivity (\%) }=\frac{[\mathrm{CO}]}{x \times\left\{\left[C_{x} H_{y}\right]_{\text {in }}-\left[C_{x} H_{y}\right]_{\text {out }}\right\}} \times 100
\end{aligned}
$$


A dielectric barrier discharge was created in the vertical tube by applying a voltage to the lower of the two external circular copper electrodes, based on thesystem described by Teschke et al .[40], whilst the upper electrode was grounded. In addition, the thermocouple placed within the reactor acted as an internal grounded electrode. A high voltage probe (Tektronix, P6015) and a calibrated Rogowski coil (Pearson) connected to a digital oscilloscope (LeCroy WavePro 7300A) were used to measure the variable, time-dependent applied voltageand current. The powered electrode was driven at peak voltages from 6 to $7 \mathrm{kV}$ and modulated from 16 to $23 \mathrm{kHz}$. Time resolved voltage and current measurements showed that the power into the plasma was between 1 and $2 \mathrm{~W}$.

\section{Results and Discussion}

\subsection{Activity tests}

Figure 2 shows the deNOx performance of the Ag catalyst at $25{ }^{\circ} \mathrm{C}$ and $250{ }^{\circ} \mathrm{C}$ using $n$ octane and toluene in the absence and presence of the NTP. Figure 2a clearly shows that, at ambient temperature and in the presence of the NTP, $\mathrm{NO}_{\mathrm{x}}$ conversions of $\sim 52 \%$ in the case of $n$-octane and $\sim 42 \%$ in the case of toluene were obtained with $\mathrm{N}_{2}$ selectivities of $\sim 78 \%$ and 96 $\%$, respectively. For $n$-octane-SCR, the $\mathrm{N}_{2} \mathrm{O}$ selectivity was $\sim 4 \%$ and $19 \%$ of unidentified Ncontaining compounds remained. For toluene-SCR, the $\mathrm{N}_{2} \mathrm{O}$ selectivity was $\sim 2 \%$ and a $2 \%$ unidentified $\mathrm{N}$-containing compounds was also observed. $\mathrm{NH}_{3}$ was not detected under any of the conditions explored. No activity was observed when the plasma was not applied.

Further reduction of $\mathrm{NO}_{\mathrm{x}}$ in the presence of toluene was obtained by increasing the temperature of the reaction to $250^{\circ} \mathrm{C}$. In the presence of the NTP (Figure 2) the conversion of $\mathrm{NO}_{x}$ reached $70 \%$, with $99 \%$ selectivity to $\mathrm{N}_{2}$ and $\sim 1 \%$ to $\mathrm{N}_{2} \mathrm{O}$. Again no conversion was observed in the absence of the NTP. A different trend was observed in the case of the $n$-octane$\mathrm{SCR}$, where the increase in temperature led to a decrease of the $\mathrm{NO}_{\mathrm{x}}$ conversion to $\sim 25 \%$, with more than $75 \%$ selectivity towards $\mathrm{N}_{2}$. This effect will be discussed in section 3.2. A small increase in $\mathrm{NO}_{\mathrm{x}}$ conversion was noted at $250{ }^{\circ} \mathrm{C}$ in the absence of NTP.

Figure $2 \mathrm{~b}$ shows that when the reaction was carried out at ambient temperature, the presence of the NTP led to $>98 \%$ conversion of the $n$-octane and $\sim 89 \%$ conversion of the toluene, compared with $<5 \%$ when the NTP was not applied. Increasing the reaction temperature to $250^{\circ} \mathrm{C}$ resulted in full consumption of the hydrocarbons. 
Of major importance is the assessment of the synergetic effect of the NTP+catalyst in the enhancement of the SCR activity at low temperatures. A comparison of the conversions and selectivities for reactions performed using the NTP in the empty reactor, the empty reactor in the presence of the thermocouple and in the presence of the catalyst within the NTP together with the thermocouple is shown in Table 1. The presence of the catalyst in the discharge area had a major effect on the conversion of the hydrocarbons and $\mathrm{NO}_{\mathrm{x}}$. For the toluene-SCR, in the presence of the NTP, the total $\mathrm{NO}_{\mathrm{x}}$ conversion was found to be $<5 \%$ in the empty reactor with an increase to $\sim 25 \%$ on introducing the thermocouple into the reactor. In the presence of the thermocouple and the $2 \% \mathrm{Ag} / \mathrm{Al}_{2} \mathrm{O}_{3}$ catalyst within the plasma discharge area, the total $\mathrm{NO}_{\mathrm{x}}$ conversion with toluene in the feed was $\sim 42 \%$. A similar trend was observed for the toluene conversion with $\sim 8 \%$ found using the empty reactor with the NTP compared with $\sim 72 \%$ in the presence of the thermocouple and $\sim 89 \%$ in the presence of the catalyst and thermocouple. A $20 \%$ decrease in the $\mathrm{N}_{2}$ formation was observed in the absence of the catalyst with the thermocouple acting as a second ground electrode, while insignificant quantities of $\mathrm{N}_{2}$ were formed when the thermocouple was removed. The selectivity towards $\mathrm{CO}_{2}$ was also improved in the presence of the catalyst and thermocouple compared with the empty reactor in the presence of the thermocouple. In the former case $90 \%$ selectivity to $\mathrm{CO}_{2}$ was observed compared with $\sim 74 \%$ in the latter arrangement. Importantly, the change in the $\mathrm{CO}_{2}$ selectivity is not due to a significant change in the CO selectivity which only decreases from $\sim 13$ to $11 \%$ on addition of the catalyst. The presence of the catalyst in the NTP eliminates the formation of other C-containing by-products, reported as "unknown products" in Table 1. In the absence of the catalyst, these represent $13 \%$ of the carbon balance. Note that under the latter conditions the reactor and quartz wool were also observed to be become discoloured.

Similarly, very low conversions were observed for the activity test on the empty reactor, in the absence of both catalyst and thermocouple for the plasma assisted n-octane-SCR. In general, higher $\mathrm{NO}_{\mathrm{x}}$ and hydrocarbon conversion were observed for the plasma assisted $n$ octane-SCR, and the trends were similar to those observed for toluene, i.e. an increase in conversions when the thermocouple was connected to the system and further improvement in the SCR activity when the catalyst was positioned in the discharge area. Importantly, despite the increase in $\mathrm{NO}_{\mathrm{x}}$ conversion from $\sim 35 \%$ in the empty reactor with the thermocouple to $\sim 52 \%$ in the presence of the catalyst and thermocouple, no significant changes were observed in the formation of ${ }^{15} \mathrm{~N}_{2}(\sim 76 \%$ compared with $\sim 78 \%$, respectively). This in a significant difference compared with the toluene-SCR reaction which showed $\sim 96 \%$ selectivity to $\mathrm{N}_{2}$ in the presence of the catalyst and thermocouple. 
Table 1. $\mathrm{NO}_{x}$ and hydrocarbon conversion and selectivity to $\mathrm{N}_{2}, \mathrm{~N}_{2} \mathrm{O}, \mathrm{CO}$ and $\mathrm{CO}_{2}$ during the toluene-SCR of ${ }^{15} \mathrm{NO}$ reaction in the presence of the NTP using the blank reactor, the reactor in the presence of the thermocouple and the reactor in the presence of the thermocouple and $2 \% \mathrm{Ag} / \mathrm{Al}_{2} \mathrm{O}_{3}$ at ambient temperature.

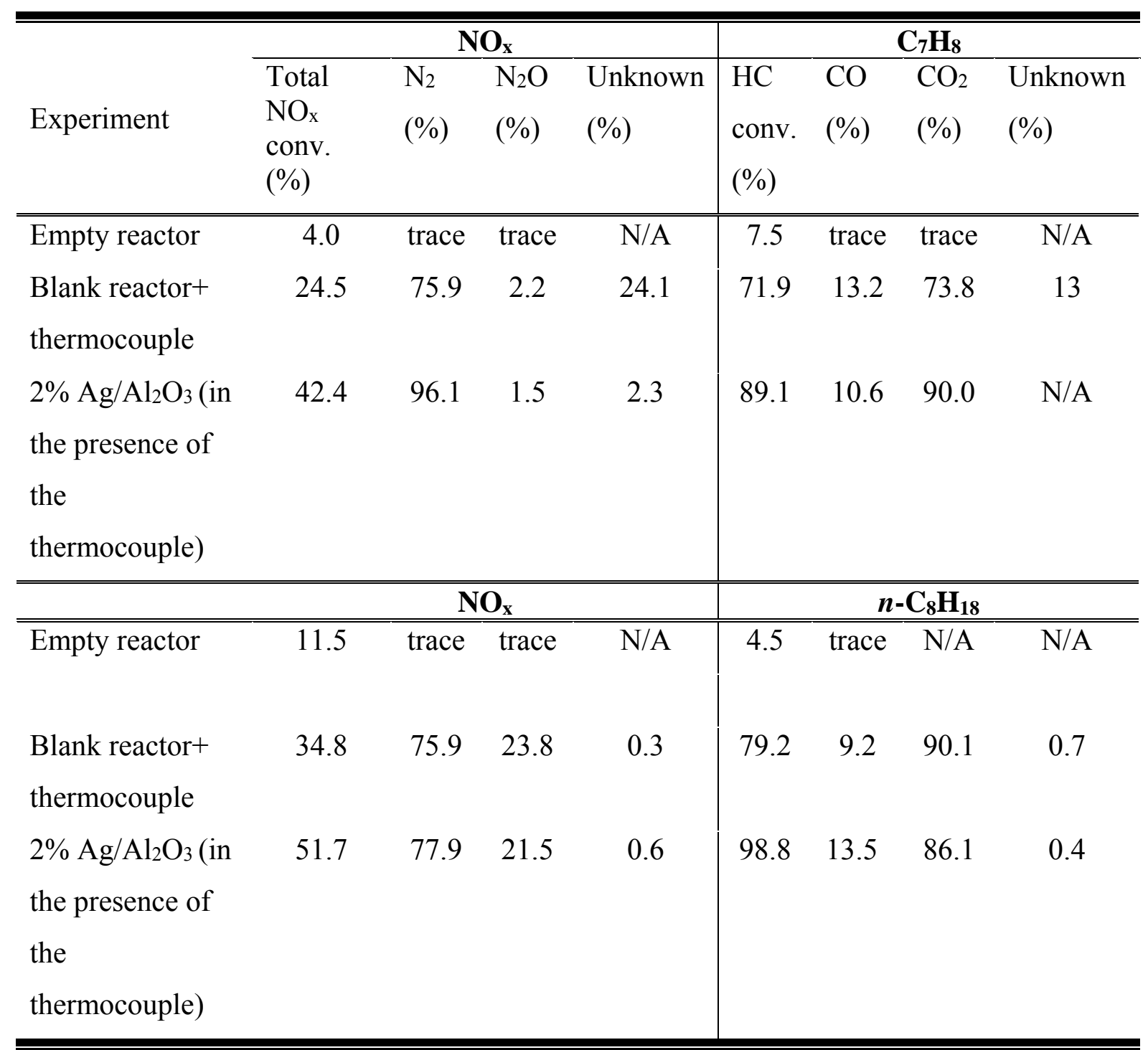

The presence of water is known to be important for the thermally activated HC-SCR reaction. Recent results showed that in the absence of water only $20 \%$ conversion of $\mathrm{NO}_{\mathrm{x}}$ was observed in comparison to $60 \%$ following the addition of $7.2 \%$ of water at $400{ }^{\circ} \mathrm{C}$ [41] Figure S1 shows the effect of the addition of water into the HC-SCR feed during the NTP activated reaction. In comparison with the SCR with $\mathrm{H}_{2} \mathrm{O}$, the SCR without $\mathrm{H}_{2} \mathrm{O}$ showed a decrease in the $\mathrm{NO}_{\mathrm{x}}$ and toluene conversion from $\sim 40 \%$ to $18 \%$ and from $\sim 90 \%$ to $80 \%$, respectively. No significant changes in selectivity were observed. 
Further experiments were performed to investigate the behaviour of the gas species when switching the plasma on and off during the toluene-SCR reaction at $250{ }^{\circ} \mathrm{C}$. FTIR spectra of the gas phase outlet as a function of switching the plasma on and off are reported in Figure $3 \mathrm{a}$. When compared with the IR spectra recorded when bypassing the reactor and when the plasma was off, significant differences could be observed in the presence of the plasma,. With an applied electrode voltageof $7 \mathrm{kV}$, it was found that the IR bands between 3100 and $2800 \mathrm{~cm}^{-1}$, assigned to the vibrational $\mathrm{C}-\mathrm{H}$ stretching of gas phase toluene, disappeared. This indicated that toluene had been activated for $\mathrm{NO}_{\mathrm{x}}$ reduction and at least partially converted to form gas phase $\mathrm{CO}_{2}$ (not shown) and $\mathrm{CO}$ (see Figure 3 ) as shown by the bands at $2143 \mathrm{~cm}^{-1}[42,43]$. No significant lag was observed between the gas phase spectra and presence or absence of the plasma indicating that the species formed are short lived and only affect the activity when the plasma is applied.

Similar effects on the hydrocarbon oxidation during plasma on-off switches were observed when the test was performedat room temperature (Figure 3b). Importantly, during these switches, the temperature of the gas was determined from the rotational structure of the $\mathrm{N}_{2}$ second positive system emission. The measurements were done at a distance between the reactor and the optical probe of $\sim 12 \mathrm{~mm}$. Figure S2 shows the best fit of simulated spectrum with the experimental data of the nitrogen emission line $(377-381 \mathrm{~nm})$, which corresponds to a rotational gas temperature of $93{ }^{\circ} \mathrm{C}(367 \mathrm{~K})$ for the $n$-octane-SCR reaction and $91{ }^{\circ} \mathrm{C}(364 \mathrm{~K})$ for the toluene-SCR reaction. Furthermore, the response of the thermocouple probe after switching off the plasma also showed a temperature of $\sim 120{ }^{\circ} \mathrm{C}$, indicating that thermal activation of the catalyst is not likely to be the cause of the enhanced activity observed.

Further studies were performed using different reactor configurations to assess their impact on the plasmas reactor performance. It was found that placing the plasma upstream of the catalyst or above but not passing through the catalyst bed had little effect on the $\mathrm{NO}_{\mathrm{x}}$ conversion. The schematics of all the reactors configurations tested are presented in the supporting information (Figure S3).

\subsection{Effect of the voltage and the frequency on the plasmareactor efficiency}

Figure 4 shows the effect of the applied voltage on plasma assisted SCR of $\mathrm{NO}_{\mathrm{x}}$ and hydrocarbon conversion at $250^{\circ} \mathrm{C}$. An increase in voltage from 6 to $7 \mathrm{kV}$ resulted in an increase in the toluene conversion from $\sim 78 \%$ to $99 \%$ together with the $\mathrm{NO}_{\mathrm{x}}$ conversion increasing from 
$44 \%$ to $71 \%$ (Figure $4 a$ ). A different trend was observed when using $n$-octane as the reductant. Figure $4 \mathrm{~b}$ shows that the $\mathrm{NO}_{\mathrm{x}}$ conversion decreased from $\sim 45 \%$ to $25 \%$ on increasing the voltage from 6 to $7 \mathrm{kV}$, while the $n$-octane was fully converted.

There is a general agreement that the activation of thehydrocarbon is a key step in the mechanism of HC-SCR of $\mathrm{NO}_{\mathrm{x}}$. It has been discussed and accepted by many researchers that the activation of both $\mathrm{NO}_{\mathrm{x}}$ and hydrocarbons leads to the formation of surface $\mathrm{NCO}$ species, which is thought to be a key intermediate and involved in the final step of the SCR reaction over $\mathrm{Ag} / \mathrm{Al}_{2} \mathrm{O}_{3}$ catalysts to form $\mathrm{N}_{2}$ [33-36, 42-45]. It was reported that aromatics (toluene in this case) are inactive at temperatures below $400{ }^{\circ} \mathrm{C}[5,46,47]$. This would indicate that the activation and partial oxidation of toluene requires more energy andsubsequently a higher temperature than $n$-octane. The SCR activity with toluene shown in Figure 4a was enhanced at low temperatures with increasing voltage. This is probably due to increased plasma energy applied at the higher voltages which promoted the activation and partial oxidation of toluene and subsequently led to increased deNOx activity. In contrast, as $n$-octane is easier to activate, an increase in the energy either by increasing the voltage or the temperature of the reaction (as shown in Figure 2) led to over oxidation of the hydrocarbon favouring total combustion rather than reaction with $\mathrm{NO}_{\mathrm{x}}$. This is similar to the effect observed in the thermally activated HC$\mathrm{SCR}$ deNO x reactions, where increases in temperature initially lead to increased $\mathrm{NO}_{\mathrm{x}}$ conversion, where partial oxidation of the HC occurs. At sufficiently high temperatures, total combustion of the hydrocarbon is dominant and the $\mathrm{NO}_{\mathrm{x}}$ conversion decreases.

The driving frequency also had a significant effect on the HC-SCR of $\mathrm{NO}_{\mathrm{x}}$. Figure S4A shows the $\mathrm{NO}_{\mathrm{x}}$ conversion obtained duringthe $n$-octane-SCR reaction performed at $250{ }^{\circ} \mathrm{C}$ as a function of the driving current frequency at $6 \mathrm{kV}$. The $\mathrm{NO}_{\mathrm{x}}$ conversion was found to decrease from $63 \%$ at $\sim 16 \mathrm{kHz}$ to $45 \%$ at $\sim 20 \mathrm{KHz}$. This behaviour mirrors the trends obtained with increasing voltages. An increase in driving frequency increases the plasma energy density and, therefore, if the energy provided exceeds that required this will lead to an enhancement of the selectivity towards total combustion and finally a reduced SCR performance. Furthermore, by varying the driving frequency not only is the $\mathrm{NO}_{x}$ conversion affected but also the $\mathrm{N}_{2} \mathrm{O}$ selectivity, as shown in Figure S4B. This is consistent with the results from thermal activation where the formation of $\mathrm{N}_{2} \mathrm{O}$ depends both on the $\mathrm{NO}_{\mathrm{x}}$ conversion and on the temperature [1], following a volcano curve. Therefore, it was possible to maximise the selectivity towards $\mathrm{N}_{2}$ compared with $\mathrm{N}_{2} \mathrm{O}$ by controlling the reaction temperature as well as the driving frequency, leading to $<15 \% \mathrm{~N}_{2} \mathrm{O}$ formation at $250{ }^{\circ} \mathrm{C}$ using a voltage of $6 \mathrm{kV}$ and a frequency of 16.3 
$\mathrm{kHz}$. However, further fine tuning of the voltage/frequency and the duration of the pulse is required in order to enhance the SCR activity for the Ag based catalyst at low temperature.

\section{Conclusions}

An atmospheric pressure non-thermal plasma jet catalytic reactor was developed. When combined with an $\mathrm{Ag} / \mathrm{Al}_{2} \mathrm{O}_{3}$ catalyst and applied to $\mathrm{HC}-\mathrm{SCR}$ of $\mathrm{NO}_{x}$, a strong enhancement was observed when compared withconventional thermal activation. In the presence of the plasma, high conversions of both $\mathrm{NO}_{\mathrm{x}}$ and hydrocarbons were obtained at temperature $\leq 250$ ${ }^{\circ} \mathrm{C}$, where the silver based catalyst is normally inactive. Importantly, significant activity was obtained at $25{ }^{\circ} \mathrm{C}$. These results provide a promising base for future development of vehicle exhaust treatment during cold start which remains a serious problem in terms of pollutants emissions.

\section{Acknowledgements}

The authors would like to thank EPSRC for financial support through the CASTech project $(\mathrm{EP} / \mathrm{G} 02152 \mathrm{X} / 1)$ and W. Adress acknowledges the support of the Iraqi Ministry of Higher Education and Scientific Research.

\section{Associated Content}

Supporting Information contains the effect of water on the toluene-SCR reaction, the experimental and simulated emission spectra during the HC-SCR reactions, the schematics of the reactor configurations tested and effect of applied current frequency on the HC-SCR reactions. This material is available free of charge via the Internet at http://pubs.acs.org.

\section{References}

[1] Burch, R.; Breen, J.P.; Meunier, F.C. Appl. Catal. B 2002, 39, 283-303.

[2] Iglesias-Juez, A.; Hungría, A.B.; Martínez-Arias, A.; Fuerte, A.; Fernándezcía, M.; Anderson, J.A.; Conesa, J.C. Soria, J. J. Catal. 2003, 217, 310-323.

[3] Lindfors, L.-E.; Eränen K.; F. Klingstedt F.; Murzin, D.Y. Top. Catal. 2004, 28, 185189.

[4] He H.; Yu, Y. Catal. Today 2005, 100, 37-47.

[5] Shimizu, K.; Satsuma, A. Phys. Chem. Chem. Phys. 2006, 8, 2677-2695. 
[6] Takagi, K.; Kobayashi, T.; Ohkita, H.; Mizushima, T.; Kakuta, N.; Abe, A.; Yoshida, K. Catal. Today 1998, 45, 123-127.

[7] Sultana, A.; Haneda, M.; Fujitani, T. Hamada, H. Catal. Lett. 2007, 114, 96-102.

[8] Li, J.; Zhu, Y.; Ke, R.; Hao J. Appl. Catal. B 2008, 80, 202-213.

[9] Li J.; Ke, R.; Li W.; Hao J. Catal. Today 2007, 126, 272-278.

[10] Kannisto, H.; Ingelsten, H. H.; Skoglundh, M. J. Mol. Catal. A 2009, 302, 86-96.

[11] Martínez-Arias, A.; Fernández-García, M.; Iglesias-Juez, A.; Anderson, J.A.; Conesa, J.C.; Soria, J. Appl. Catal. B 2000, 28, 29-41.

[12] Shimizu, K.; Satsuma, A.; Hattori, T. Appl. Catal. B 2000, 25, 239-247.

[13] Shimizu, K.; Shibata, J.; Yoshida, H.; Satsuma, A.; Hattori, T. Appl. Catal. B 2001, 30, 151-162.

[14] Mizuni, A. Catal. Today 2013, 211, 2-8.

[15] Hessel, V.; Anastasopoulou, A.; Wang, Q,; Kolb, G.; Lang, J. Catal. Today 2013, 211, 9-28.

[16] Oda, T. J. Electrostat. 2003, 57, 293-311.

[17] Durme, J.V.; Dewulf, J.; Leys, C.; Langenhove, H.V. Appl. Catal. B 2008, 78, 324-333.

[18] Than Quoc An, H.; Pam Huu, T.; Le Van, T.; Cormier. J.M.; Khacel, A. Catal. Today 2011, 176, 474-477.

[19] Tang, X.; Feng, F.; Ye, L.; Zhang, X.; Huang, Y.; Liu, Z. Catal Today 2013, 211, 39-43.

[20] Shi, C.; Zhang, Z.; Crocker, M.; Xu, L.; Wang, C.; Au, C.; Zhu, A. Catal. Today 2013, 211, 96-103.

[21] Zhou, T.; Jang, K.; Lang, B.W.L. Catal. Today 2013, 211, 147-155.

[22] Lee, D.H.; Lee, J.-O.; Kim, K.-T.; Song, Y.-H.; Kim, E.; Han, H.-K. Int. J. Hydrogen Energ. 2011, 36, 11718-11726.

[23] Lee, D.H.; Lee, J.-O.; Kim, K.-T.; Song, Y.-H.; Kim, E.; Han, H.-K. Int. J. Hydrogen Energ. 2012, 37, 3225-3233.

[24] Wang, H.; Li, X.; Chen, M.; Zheng, X. Catal. Today 2013, 211, 66-71.

[25] Matsumoto T.; Wang, D.; Namihira, T.; Akiyama, H. Chapter 9: Non-Thermal Plasma technic for Air Pollutoion Caontrol, INTECH 2012.

[26] Rappé, K.G.; Hoard, J.W.; Aardahl, C.L.; Park, P.W.; Peden, C.H.F.; Tran, D.N. Catal. Today 2004, 89, 143-150.

[27] Cho, B.K.; Lee, J.-H.; Crellin, C.C.; Olson, K.L.; Hilden, D.L.; Kim, M.K.; Kim, P.S.; Heo, I.; Oh, S.H.; Nam, I.-S. Catal. Today 2012, 191, 20-29. 
[28] Harling, A.M.; Demidyuk, V.; Fischer, S.J.; Whitehead, J.C. Appl. Catal. B 2008, 82, 180.

[29] Wang, H. Chem. Commun. 2013, 49, 9353-9355.

[30] Magureanu, M.; Piroi, D.; Mandache, N.B.; Pârvulescu, V.I.; Pârvulescu, V.;

Cojocaru, B.; Cadigan, C.; Richards, R.; Daly, H.; Hardacre, C.; Appl. Catal. B 2011, $104,84-90$

[31] Okubo, M.; Tanioka, A.; Kuroki, T.; Yamamoto, T. IEEE. T. Ind. App. 2002, 38, 11961203.

[32] Kim, H.H.; Ogata. A.; Futamura S. Appl. Catal. B 2008, 79, 256-267.

[33] Yu, Q.Q.; Wang, H.; Liu, T.; Xiao, L.P. Jiang, X.Y., Zheng, X.M. Environ. Sci. Tech. 2012, 46, 2337-2344.

[34] Chansai, S.; Burch, R.; Hardacre, C.; Breen, J.; Meunier, F. J. Catal. 2010, 276, 49-55.

[35] Chansai, S.; Burch, R.; Hardacre, C.; Breen, J.; Meunier, F. J. Catal. 2011, 281, 98-105.

[35] Breen, J.P.; Burch, R.; Hardacre, C.; Hill, C.J.; Rioche, C. J. Catal. 2007, 246, 1-9.

[37] Twomey, B.; Nindrayog, A.; Niemi , K.; Graham, W. G.; Dowling, D. P. Plasma Chem. Plasma Process 2011, 31, 139-156.

[38] Lu, X.; Xiong, Q.; Xiong, Z.; Hu, J.; Zhou, F.; Gong, W.; Xian, Y.; Zou, C.; Tang, Z.; Jiang, Z.; Pan, Y. J. Appl. Phys. 2009, 105, 043304.

[39] Nastuta, A.V.; Topala, I.; Grigoras, C.; Pohoata, V.; Popa, G. J. Phys. D: Appl. Phys. 2011, 44, 105204.

[40] Teschke, M.; Kedzierski, J.; Finan-Dinu, E.G.; Korzec, D.; Engrmann, J. IEEE.T.Plasma Sci. 2005, 33, 310.

[41] Ralphs, K.; D’Agostino, C.; Burch, R.; Chansai, S.; Gladden, L.F., Hardacre, C.; James, S.L.; Mitchell, J.; Taylor, S. F. R. Catal. Sci. Technol. 2014. accepted, DOI: 1$.1039 / \mathrm{c} 3 \mathrm{cy} 00945 \mathrm{a}$

[42] Meunier, F.C.; Breen, J.P.; Zuzaniuk, V.; Olsson, M.; Ross, J.R.H. J. Catal. 1999, 187, 493-505.

[43] Bion, N.; Saussey, J.; Haneda, M.; Daturi, M. J. Catal. 2003, 217, 47-58.

[44] Tamm, S.; Ingelsten, H.H.; Palmqvist, A.E.C. J. Catal. 2008, 255, 304-312

[45] Eränen, K.; Klingstedt, F.; Arve, K.; Lindfors, L.-E.; Murzin, D.Y. J. Catal. 2004, 227, 328-343.

[46] Demidyuk, V.; Hardacre, C.; Burch, R.; Mhadeshwar, A.; Norton, D.; Hancu, D. Catal. Today 2011, 164, 515-519. 
[47] Kim, M.K.; Kim, P.S. Baik J.H. Nam. I.-S.; Cho, B.K.; Oh, S.H. Appl. Catal. B 2011, 105, 1-14. 
Figures and Captions
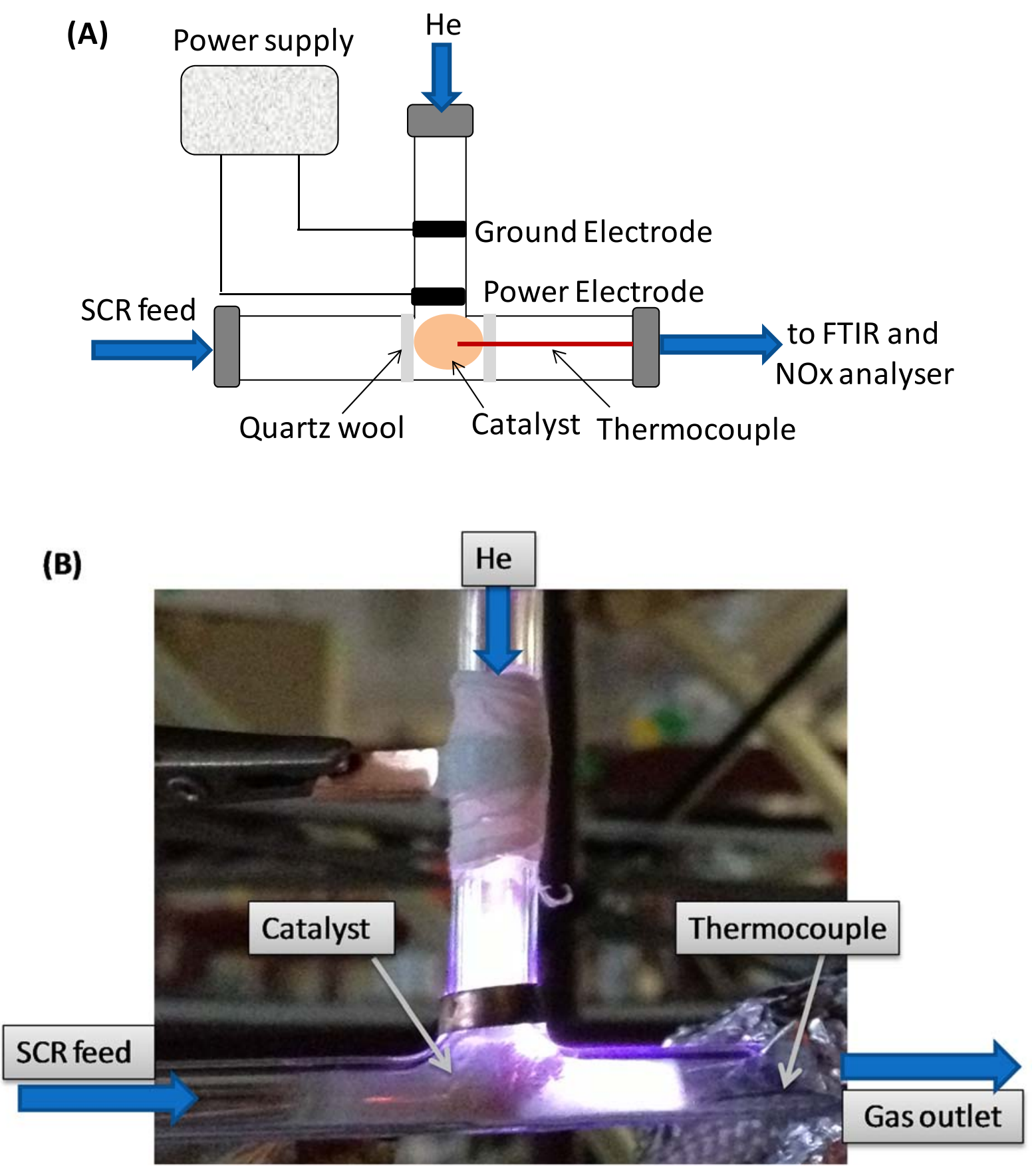

Figure 1. Schematic (A) and photograph (B) of the plasma reactor used during the HC-SCR activity test. 

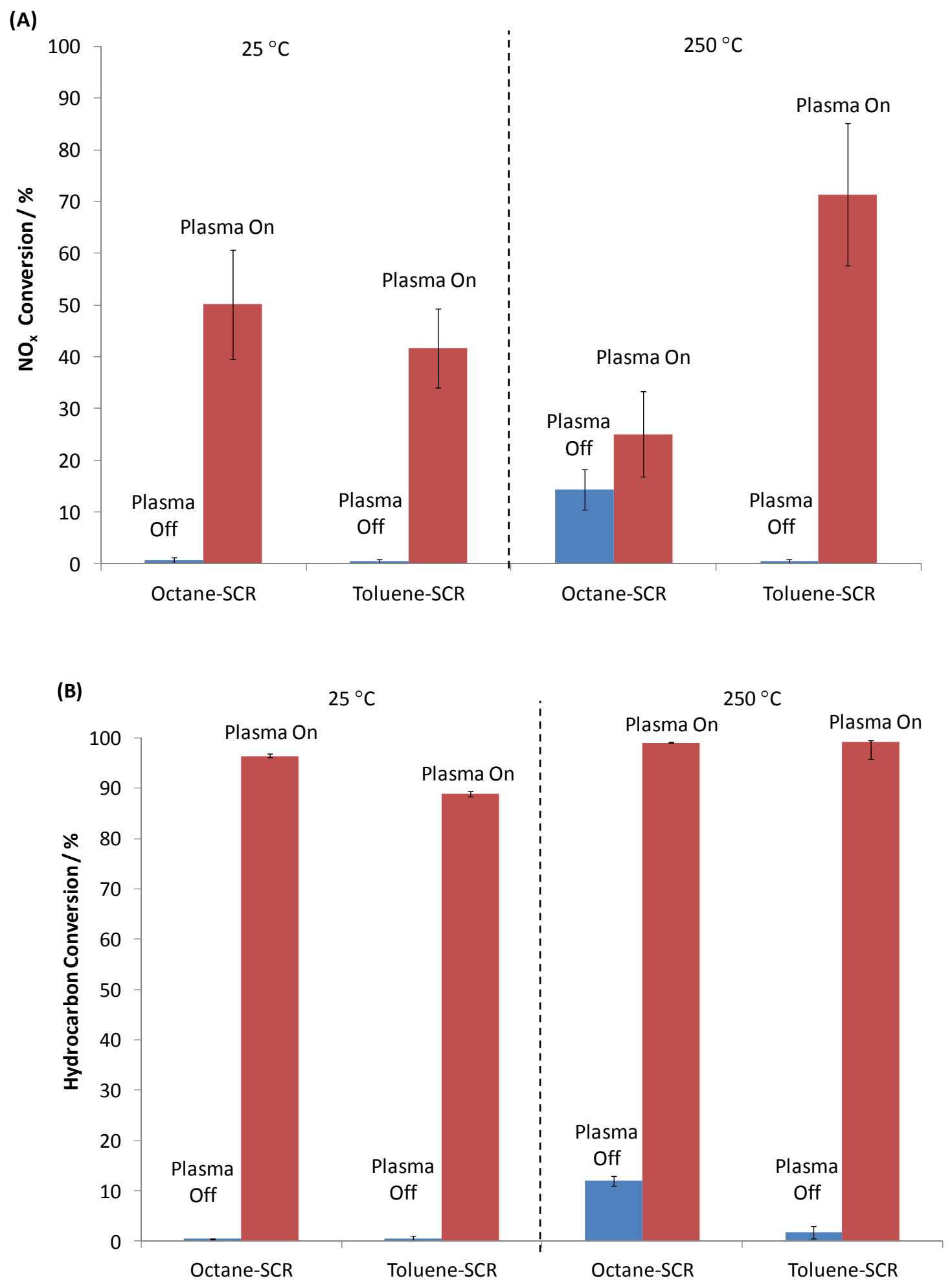

Figure 2. $\mathrm{NO}_{\mathrm{x}}(\mathrm{a})$ and hydrocarbon (b) conversion during the $\mathrm{HC}-\mathrm{SCR}$ of $\mathrm{NO}_{\mathrm{x}}$ reaction over 2 wt $\% \mathrm{Ag} / \mathrm{Al}_{2} \mathrm{O}_{3}$. Feed composition: 720 ppm NO, 4340 ppm (as $\mathrm{C} 1$ ) $\mathrm{HC}, 4.3 \% \mathrm{O}_{2}, 7.2 \% \mathrm{CO}_{2}$, $7.2 \% \mathrm{H}_{2} \mathrm{O}$ and $\mathrm{He}$ balance. The total flow rate and space velocity was $276 \mathrm{~cm}^{3} \mathrm{~min}^{-1}$ and 165600 $\mathrm{cm}^{3} \mathrm{~g}^{-1} \mathrm{~h}^{-1}$, respectively. 

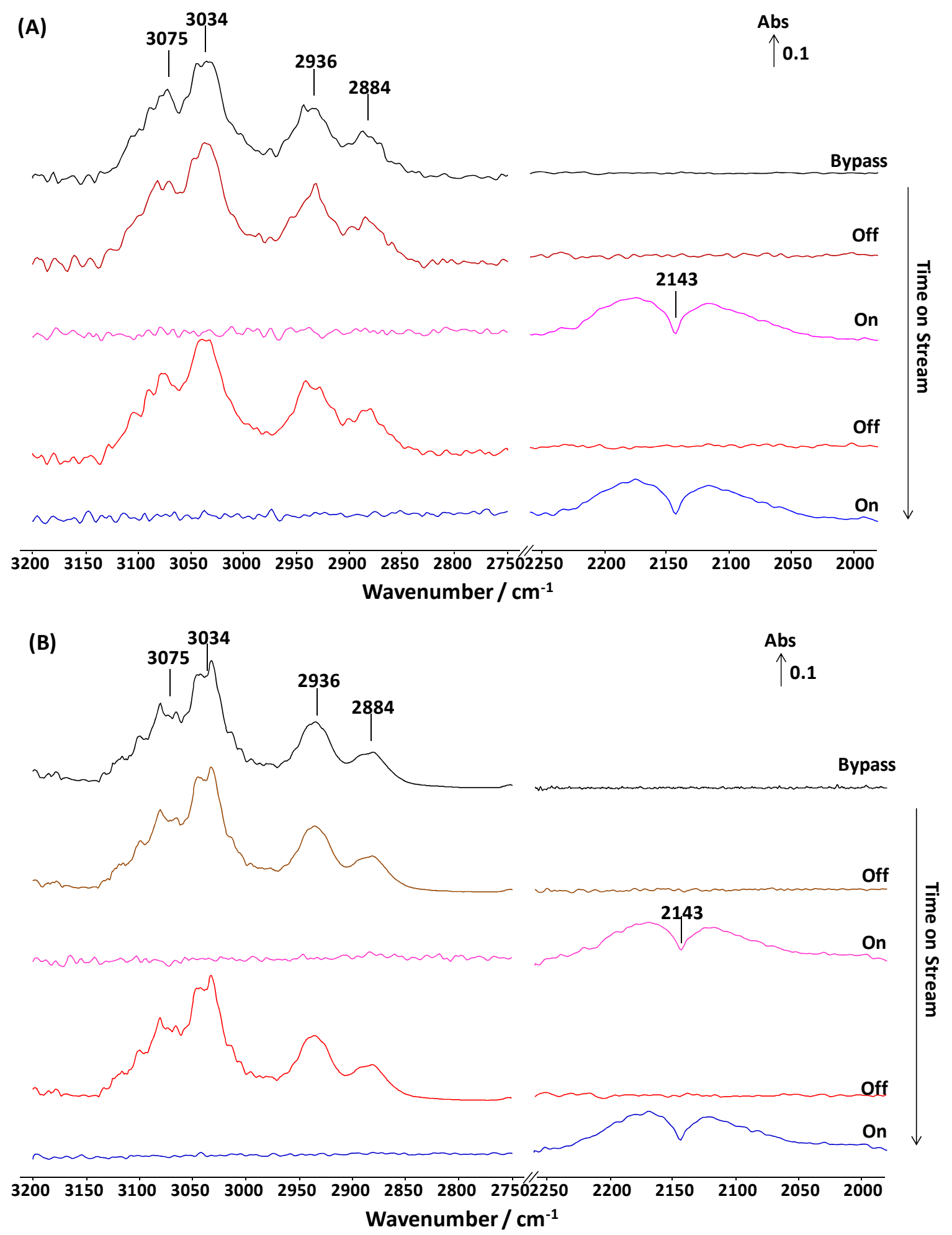

Figure 3. FTIR spectra of gas phase species recorded during switching $7 \mathrm{kV}, 19 \mathrm{kHz}$ plasma on and off under toluene-SCR of $\mathrm{NO}_{x}$ reaction conditions over $2 \% \mathrm{Ag} / \mathrm{Al} \mathrm{O}_{3}$ catalyst at (A) $250^{\circ} \mathrm{C}$ and (B) $25^{\circ} \mathrm{C}$. Feed conditions: $720 \mathrm{ppm} \mathrm{NO}, 4.3 \% \mathrm{O}_{2}$, $4340 \mathrm{ppm}$ (as $\mathrm{C}_{1}$ ) toluene, $7.2 \%$ $\mathrm{CO}_{2}, 7.2 \% \mathrm{H}_{2} \mathrm{O}$, He Balance. The total flow rate and space velocity was $276 \mathrm{~cm}^{3} \mathrm{~min}^{-1}$ and $165,600 \mathrm{~cm}^{3} \mathrm{~g}^{-1} \mathrm{~h}^{-1}$, respectively. 

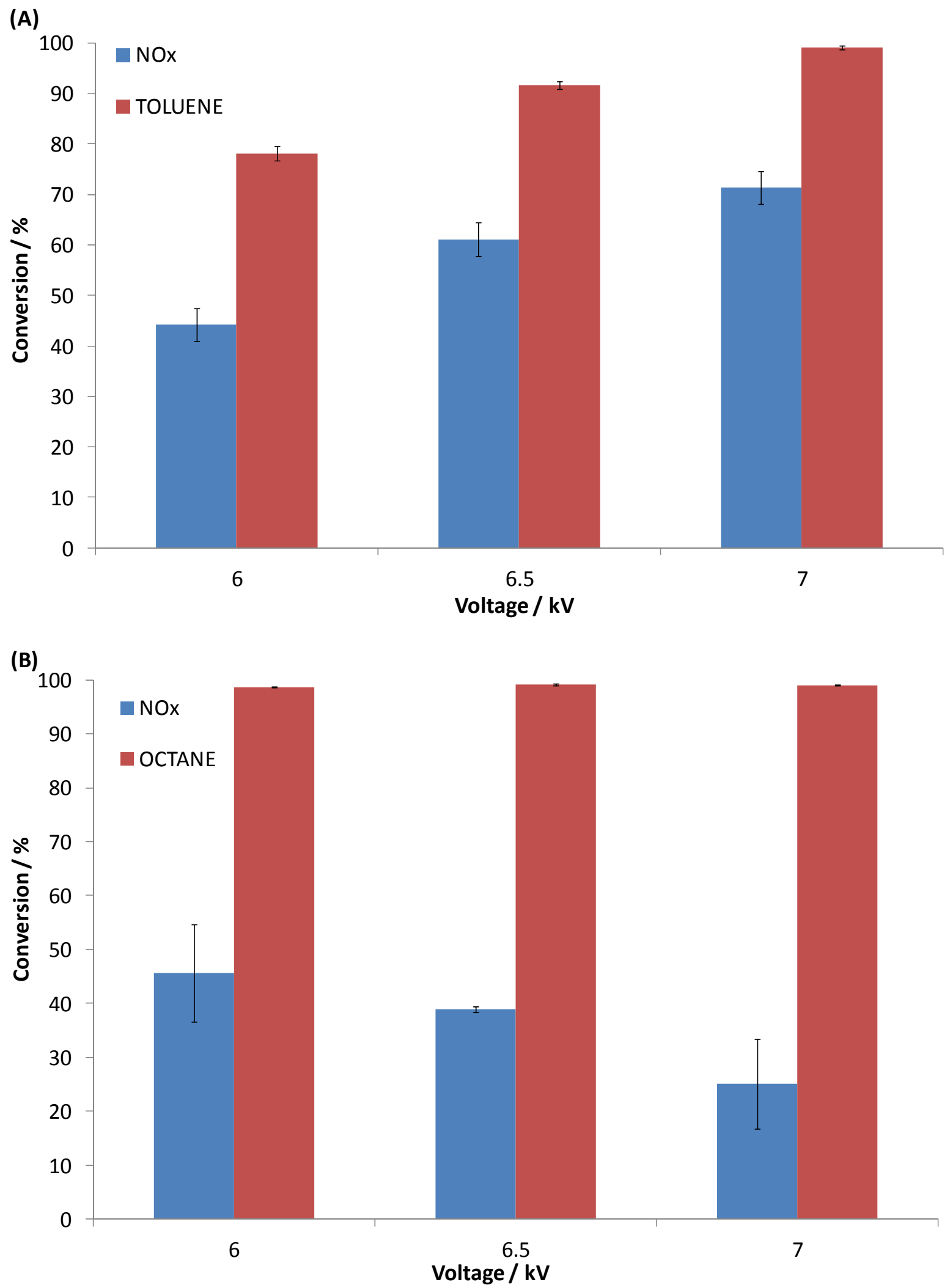

Figure 4. The effect of applied voltage on the $\mathrm{NO}_{\mathrm{x}}$ conversion at $19 \mathrm{kHz}$ during the $\mathrm{SCR}$ reaction over $2 \%$ wt $\mathrm{Ag} / \mathrm{Al}_{2} \mathrm{O}_{3}$ with toluene (A) and $n$-octane (B) at $250{ }^{\circ} \mathrm{C}$. Feed conditions: 720 ppm NO, 4.3\% $\mathrm{O}_{2}$, 4340 ppm (as $\left.\mathrm{C}_{1}\right) \mathrm{HC}, 7.2 \% \mathrm{CO}_{2}, 7.2 \% \mathrm{H}_{2} \mathrm{O}$, He Balance. The total flow rate and space velocity was $276 \mathrm{~cm}^{3} \mathrm{~min}^{-1}$ and $165,600 \mathrm{~cm}^{3} \mathrm{~g}^{-1} \mathrm{~h}^{-1}$, respectively. 